\title{
JOURNAL.RU
}

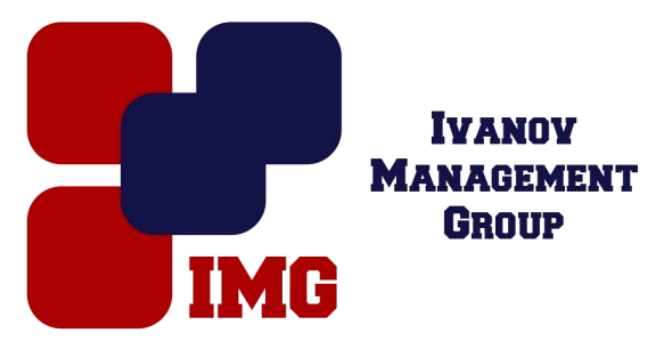

Шепель Л.А, Андриянова Н.В. СГТУ ил. Ю.А. Гагарина Саратов, Россия

doi: 10.18411/lj-31-10-2016-2-11

idsp 000001:lj-31-10-2016-2-11

\section{Улучшение конструкции сетчатого эндопротеза}

Научный руководитель: Пичхидзе С.Я.

Цель работы: улучшить конструкцию сетчатого эндопротеза, увеличить срок службы.

Для улучшения качества и характеристики сетчатого эндопротеза рис.1, размером 90×90 мм, толщиной 1,5 мм, он был изготовлен из $100 \%$ волокна фторопласта-4 - ПТФЭ, отличающегося высокой биологической инертностью. Это обеспечит прорастание имплантата в организм, т.к. волокнистая структура и высокая прочность на разрыв позволяют надёжно закрепить имплантат нитью при операциях.

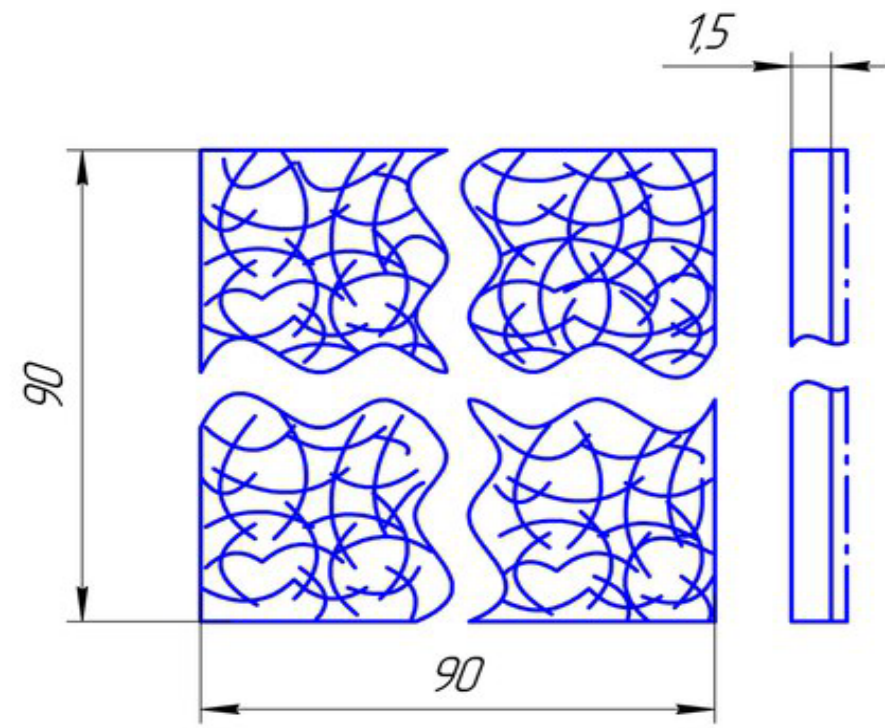

Рис.1. Сетчатый эндопротез 
Выводы: усовершенствована конструкция сетчатого эндопротеза, состоящего из ПТФЭ и биоактивного покрытия из Zn-ГА, обладающего антибактериальным свойством.

\section{Литература}

1. http://www.volot.ru/articles/details/54.htm.

2. http://www.urocenter.kz/?Action=Bol\&SelectBolMenu=8. 